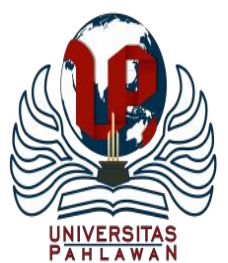

Edukatif : Jurnal Ilmu Pendidikan Volume 3 Nomor 4 Tahun 2021 Halm 2359 - 2371

EDUKATIF: JURNAL ILMU PENDIDIKAN

Research \& Learning in Education

https://edukatif.org/index.php/edukatif/index

\title{
Studi Kelayakan dan Perancangan Arbook Indonesian History: Media Pembelajaran Sejarah Menggunakan Augmented Reality
}

\author{
Hardika Dwi Hermawan $^{1 凶}$, Thaufik Probowasito ${ }^{2}$, Agatha Saputri ${ }^{3}$, Dita Puji Rahayu ${ }^{4}$, Nur \\ Kholifah Putri Taufani ${ }^{5}$ \\ Universitas Muhammadiyah Surakarta, Indonesia ${ }^{1}$ \\ Monash University, Australia, ${ }^{2}$ \\ Universitas Negeri Yogyakarta, Indonesia ${ }^{3,4}$ \\ Universitas Sebelas Maret, Indonesia ${ }^{5}$

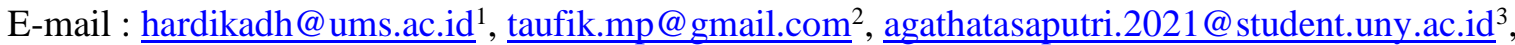 \\ ditapuji@uny.ac.id ${ }^{4}$, nur.kholifah58@ student.uns.ac.id $^{5}$
}

\begin{abstract}
Abstrak
Dimasa transformasi digital yang begitu pasif, masyarakat Indonesia mengalami penurunan dalam kehidupan berbangsa yang salah satunya diakibatkan karena kurangnya pemahaman terhadap nilai-nilai sejarah. Tujuan penelitian ini adalah untuk membangun aplikasi ARBook sebagai media pembelajaran sejarah Indonesia. Metode yang digunakan untuk membangun aplikasi ARBook adalah Research and Development. Tahapan pertama dilakukan analisis kebutuhan dan studi literatur. Tahapan kedua dilakukan dengan melakukan desain aplikasi menggunakan usecase. Tahapan ketiga yaitu implementasi atau pembangunan aplikasi dan buku kerajinan Jogja serta pengujian uji fungsional oleh ahli media. Tahapan ke empat merupakan tahapan pengujian perangkat lunak meliputi 2 tahapan pengujian yaitu uji verifikasi dan validasi serta mengetahui kualitas dan kelayakan. Hasil analisis kualitas aplikasi ARBook sejarah Indonesia memperoleh hasil dari segi fungsionality sebesar $87,5 \%$, reliability 80,0\%, portability 80,0\%, maintainability 80,0\%, dan dari segi efficiency sebesar 70\%. Secara keseluruhan presentasi kualitas aplikasi adalah sebesar 79,5\% dan masuk katagori "Baik" sehingga aplikasi layak digunakan sebagai media pembelajaran sejarah Indonesia.
\end{abstract}

Kata Kunci: media pembelajaran, sejarah, augmented reality, pembelajaran.

\begin{abstract}
In the massive transformative era, Indonesian people has experience in term of national life, which is caused by lack of understanding the nation history. The purpose of this study is to build an ARBook application as an Indonesian history learning media using Augmented Reality. The method used to build the ARBook application is Research and Development. The first stage is a needs analysis and literature study. The second stage is done by designing the application using a use case. The third stage is the implementation or development of applications and Jogja Handicraft Books as well as functional test testing by media experts. The fourth stage is the software testing stage which includes 2 stages of testing, namely verification and validation tests and knowing the quality and feasibility. The results of the analysis of the quality of the ARBook History Indonesia obtained results in terms of functionality of $87.5 \%$, reliability $80.0 \%$, portability $80.0 \%$, maintainability $80.0 \%$, and in terms of efficiency of $70 \%$. Overall, the presentation quality of the application is $79.5 \%$ and is in the "Good" category so that the application is suitable for use as a medium for learning Indonesian history.
\end{abstract}

Keywords: learning media, history, augmented reality, learning.

Copyright (c) 2021 Hardika Dwi Hermawan, Thaufik Probowasito, Agatha Saputri, Dita Puji Rahayu, Nur Kholifah Putri Taufani

$\triangle$ Corresponding author

Email : hardikadh@ums.ac.id

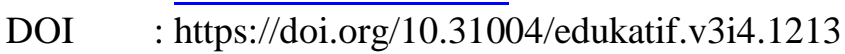

ISSN 2656-8063 (Media Cetak)

ISSN 2656-8071 (Media Online) 
2360 Studi Kelayakan dan Perancangan Arbook Indonesian History: Media Pembelajaran Sejarah Menggunakan Augmented Reality - Hardika Dwi Hermawan, Thaufik Probowasito, Agatha Saputri, Dita Puji Rahayu, Nur Kholifah Putri Taufani

DOI: https://doi.org/10.31004/edukatif.v3i4.1213

\section{PENDAHULUAN}

Sejarah menjadi hal yang penting dalam proses mempertahankan semangat nasionalisme, nilai-nilai, moral dan meningkatkan harkat dan martabat bangsa. Namun, di era globalisasi dan digitalisasi ini Indonesia mengalami kemerositan moral dan penurunan tingkat kesadaran dalam berbangsa (Syahbandi, 2021). (Agustin, 2011) menyebutkan bahwa telah terjadi penurunan rasa cinta budaya dan nasionalisme pada generasi muda di Indonesia sebagai akibat dari arus globalisasi. Jika hal-hal seperti ini tidak mendapatkan perhatikan lebih, maka sangat tidak mungkin generasi muda akan kehilangan nilai-nilai luhur bangsa dan semangat nasionalismenya. Hasil wawancara yang dilakukan terhadap guru mata pelajaran sejarah juga mengungkapkan bawah anak muda sekarang cenderung acuh terhadap sejarah, nilai pelajaran sejarah cenderung rendah dibanding mata pelajaran lainnya.

Pembelajaran sejarah yang dilakukan di sekolah banyak sebatas teori dan informasi yang tidak atraktf dan kurang melibatkan siswa dalam pembelajarannya. Kondisi memprihatinkan seperti ini memerlukan perhatian lebih dari berbagai kalangan, tidak terkecuali civitas akademika yang juga memiliki kewajiban untuk melakukan pengabdian terhadap masyarakat. Pengemasan pembelajaran sejarah seharusnya menarik dan memotivasi anak.

(Hasan, 2019) mengungkapkan bahwa pendidikan sejarah untuk kehidupan abad 21 perlu menghendaki adanya perubahan dalam komponen pembelajaran. Perubahan komponen tersebut termasuk dalam hal kompetensi mengenal dan memahami perubahan, termasuk didalamnya perlu adanya perubahan dalam hal sumber materi pendidikan sejarah. Sumber materi pendidikan sejarah sudah seharusnya tidak hanya mengandalkan texbook semata, namun juga dengan memanfaatkan media pebelajaran sejarah era teknologi informasi. (Azmi, 2015) menyatakan bahwa dalam perkembangan teknologi informasi, media pembelajaran sejarah sudah seharusnya diarahkan pada sarana mobile technology dan beracuan pada digitalisasi. Hal tersebut sejalan dengan (Suryani, 2016) yang melakukan penelitian tentang pengembangan media pembelajaran sejarah berbasis teknologi informasi dan menunjukan hasil yang postive.

Media pembelajaran telah banyak dikembangkan di Indonesia untuk meningkatkan motivasi belajar (Hae \& Rezeki Patricia Tantu, 2021); (Aprilia \& Iswendi, 2021); (Saputri et al., 2020). Beragam media pembelajaran sejarah tidak berhasil dikembangkan, diantaranya media audio visual yang dikembangkan oleh (Ainina, 2014). Penelitian (Ainina, 2014) menghasilkan bahwa media audio visual mempengarhui hasil belajar siswa kelas XI dalam materi sejarah. Penelitian lain yang dilakukan oleh (Wahyudhi, 2014) juga menunjukan adanya pengaruh postive daam pembelajaran yang memanfaatkan teknologi informasi, dalam hal ini (Wahyudhi, 2014) menggunakan video game sebagai media pembalajaran sejarah.

Kemunculan teknologi komputer bernama Augmented Reality (AR) dapat menggabungkan dunia virtual dan dunia nyata secara real time menjadi salah satu media bagi para developer untuk menyalurkan kemampuannya dalam mengembangkan aplikasi yang dapat bermanfaat bagi pembelajaran (Hermawan \& Arifin, 2015). AR tidak hanya membantu meningkatkan motivasi pengguna, namun juga dapat meningkatkan imajinasi moral dari penggunanya (Sari et al., 2021). AR dalam media pembelajaran sejarah sudah dikembangkankan dalam beberapa tahun terakhir, seperti media informasi sejarah kota medan yang dikembangkan oleh (Syahputra et al., 2020), pengembangan media pembelajaran sejarah AR Candi-Candi masa singosari (Efendi, et al., 2018), dan pengenalan bangunan sejarah kota jambi menggunakan AR (Nugroho et al., 2019). Ketiga penelitian tersebut menunjukan hasil yang postive dalam hal mengenalkan sejarah.

Oleh karena itu, urgensi peningkatan pemahaman sejarah indonesia melalui inovasi media pembelajaran sejarah yang dapat mendorong siswa untuk ikut lebih terlibat dalam pembelajaran perlu dikembagkan. Tujuan dari penelitian ini adalah mengembangkan aplikasi ARBook Indonesian History sebagai media pembelajaran 
2361 Studi Kelayakan dan Perancangan Arbook Indonesian History: Media Pembelajaran Sejarah Menggunakan Augmented Reality - Hardika Dwi Hermawan, Thaufik Probowasito, Agatha Saputri, Dita Puji Rahayu, Nur Kholifah Putri Taufani

DOI: https://doi.org/10.31004/edukatif.v3i4.1213

sejarah Indonesia menggunakan Augmented Reality serta mengetahui kelayakan media tersebut untuk digunakan sebagai media pembelajaran sejarah.

\section{METODE PENELITIAN}

Penelitian ini dilakukan dengan metode penelitian Research and Development. (Sugiyono, 2009) dalam bukunya menyebutkan penelitian Research and Development merupakan metode penelitian yang digunakan untuk menghasilkan produk tertentu dan menguji kefektifan produk tersebut. (Laws et all, 2013) mengembangkan tahapan yang digunakan dalam metode Research and development, yang dapat digambarkan sebagai berikut :

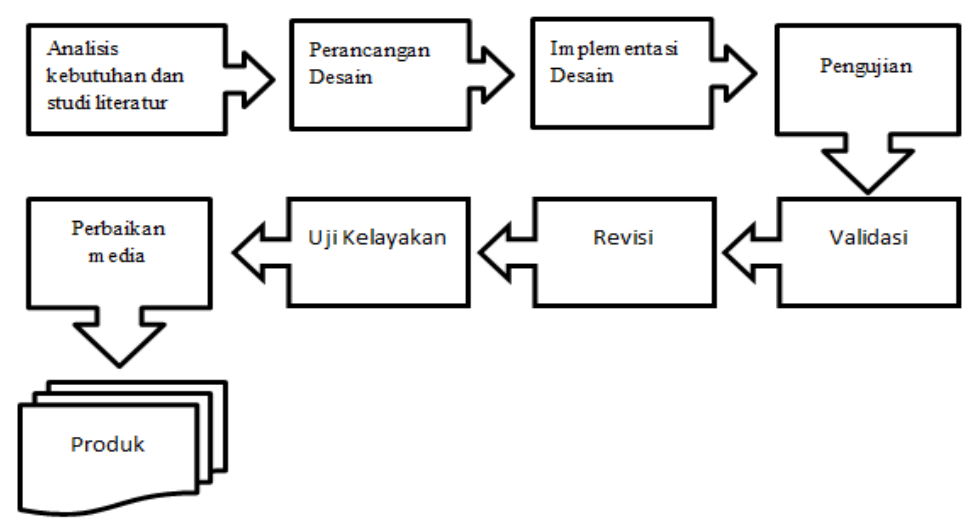

Gambar 1. Tahapan Research and Development

Teknik pengumpulan data dalam penelitian ini adalah dengan observasi dan kuesioner. Teknik pengumpulan data dengan observasi merupakan salah satu teknik pengumpulan data dengan melakukan pengamatan secara langsung terhadap objek yang diteliti. Observasi yaitu melakukan pengamatan secara langsung ke objek penelitian untuk melihat lebih dekat kegiatan yang dilakukan (Riduwan Engkos, 2012). Teknik observasi digunakan untuk melakukan pengamatan objek penelitian perangkat lunak ARBook Sejarah.

Sedangkan angket atau questionnaire merupakan metode pengumpulan data dengan menggunakan daftar pertanyaan. Jenis angket sendiri dibedakan menjadi dua jenis. Angket dibagi menjadi angket terbuka dan angket tertutup (Riduwan Engkos, 2012). Angket tertutup sebagai alat pengumpulan data pada penelitian ini. Untuk mempermudah dalam penghitungan hasil pengambilan data, digunakan skala pengukuran. Skala pengukuran yang digunakan yaitu skala Gutman dan skala Likert.

Analisa data yang digunakan pada penelitian ini menggunakan teknik analisa skala Likert. Proses analisa ini digunakan untuk menghitung data variabel yang diujikan yaitu software quality factors ISO 9126 pada aspek functionality, reliability, usability, efficiency, maintainability, dan portability. Data kuantitatif pada penelitian ini nantinya akan dirubah menjadi data kualitatif dengan menggunakan analisis Likert. Berdasarkan hasil analisis instrumen nantinya akan didapatkan skor per instrumen kemudian nanti akan dihitung rata - rata dari instrument dengan menggunakan rumus :

(1) Rumus Perhitungan rata-rata instrumen : $\bar{x}=\frac{\sum x}{n}$

$$
\text { Dimana } \begin{aligned}
\bar{x} & =\text { Skor rata-rata } \\
\sum x & =\text { Skor total item } \\
\mathrm{n} \quad & =\text { Jumlah Item }
\end{aligned}
$$

(2) Rumus perhitungan persentase skor ditulis dengan rumus berikut:

$$
\text { Persentase Kelayakan }(\%)=\frac{\text { Skor yang diobservasi }}{\text { Skor yang diharapkan }} \times 100 \%
$$


2362 Studi Kelayakan dan Perancangan Arbook Indonesian History: Media Pembelajaran Sejarah Menggunakan Augmented Reality - Hardika Dwi Hermawan, Thaufik Probowasito, Agatha Saputri, Dita Puji Rahayu, Nur Kholifah Putri Taufani

DOI: https://doi.org/10.31004/edukatif.v3i4.1213

Setelah didapatkan hasil presentasi dari perhitungan sebelumnya, kemudian data dikonversi ke dalam pernyataan predikatdengan menggunakan skala linkert. Konversi persentase ke pernyataan seperti dalam tabel 1 (Riduwan Engkos, 2012). Supaya konversi persentase ke dalam bentuk pernyataan lebih sesuai dengan penelitian yang dilakukan maka skala konversi persentase diatas disesuaikan interpretasinya. Penyesuaian interpretasi tersebut dikarenakan penelitian ini melakukan uji kelayakan perangkat lunak yang dikembangkan. Skala konversi persentase disesuaikan menjadi seperti pada Tabel 2.

Tabel 1. Interpretasi Persentase Likert

\begin{tabular}{lll}
\hline No & Presentase & Interpretasi \\
\hline $\mathbf{1}$ & $0 \%-20 \%$ & Sangat Lemah \\
\hline $\mathbf{2}$ & $21 \%-40 \%$ & Lemah \\
\hline $\mathbf{3}$ & $41 \%-60 \%$ & Cukup \\
\hline $\mathbf{4}$ & $61 \%-80 \%$ & Kuat \\
$\mathbf{5}$ & $81 \%-100 \%$ & Sangat Kuat \\
\hline
\end{tabular}

Tabel 2. Penyesuaian Interpretasi Likert

\begin{tabular}{ccc}
\hline No & Presentase & Interpretasi \\
\hline $\mathbf{1}$ & $0 \%-20 \%$ & Sangat Tidak Layak \\
\hline $\mathbf{2}$ & $21 \%-40 \%$ & Tidak Layak \\
\hline $\mathbf{3}$ & $41 \%-60 \%$ & Cukup Layak \\
\hline $\mathbf{4}$ & $61 \%-80 \%$ & Layak \\
\hline $\mathbf{5}$ & $81 \%-100 \%$ & Sangat Layak \\
\hline
\end{tabular}

Dari hasil perhitungan analisa data penelitian nantinya akan didapat interpretasi kelayakan perangkat lunak yang dikembangkan dan diteleti. Hasil penelitian ini nantinya akan menentukan kualitas perangkat lunak baik per-faktor kualitas maupun secara keseluruhan.

\section{HASIL DAN PEMBAHASAN PENELITIAN}

\section{Perancangan Desain}

\section{Analisis Kebutuhan}

Pada tahap ini, peneliti melakukan analisis kebutuhan terhadap kebutuhan perangkat lunak yang akan dikembangkan. Analisis dilakukan dengan melakukan observasi terhadap perangkat lunak yang sudah ada serta melakukan studi literatur untuk mendukung landasan pembuatan ARBook-Sejarah Indonesia.

a. Kebutuhan Fungsional

1) Aplikasi dapat membuka kamera;

2) Aplikasi dapat membaca marker sejarah Indonesia;

3) Aplikasi dapat menampilkan video sejarah Indonesia;

4) Aplikasi dapat membaca marker hingga jarak >1,5 meter;

5) Aplikasi dapat menggunakan flash;

6) Aplikasi dapat menggunakan autofocus kamera;

7) Aplikasi dapat menggunakan kamera depan;

8) Aplikasi dapat menggunakan kamera belakang;

9) Aplikasi dapat mengatur play dan pause video;

10) Aplikasi dapat menampilkan tampilan fullscreen;

11) Aplikasi dapat menampilkan bantuan. 
2363 Studi Kelayakan dan Perancangan Arbook Indonesian History: Media Pembelajaran Sejarah Menggunakan Augmented Reality - Hardika Dwi Hermawan, Thaufik Probowasito, Agatha Saputri, Dita Puji Rahayu, Nur Kholifah Putri Taufani

DOI: https://doi.org/10.31004/edukatif.v3i4.1213

b. Kebutuhan Pengembang

Tools yang dipakai dalam pengembangan media tersebut sebagai berikut :

1) Kebutuhan Hardware

a) Laptop/Komputer

b) Smartphone Android

2) Kebutuhan Software
a) Eclipse IDE
b) Android SDK
c) Android ADT
d) Vuforia SDK
e) UML
f) Perancangan Desain

Desain

Desain perangkat lunak adalah proses multi langkah yang fokus pada desain pembuatan program. Fokus desain pada tahap ini termasuk di dalamnya struktur data, arsitektur perangkat lunak, representasi antar muka dan prosedur pengkodean. Desain pengembangan perangkat lunak ini nanti akan digunakan sebagai acuan dalam melakukan pengkodean perangkat lunak. Desain pengembangan dibuat menggunakan UML sebagai bahasa pemodelan berorientasi objek.

a. Diagram Usecase

Diagram usecase digunakan untuk mengetahui fungsi apa saja yang ada di dalam sebuah sistem dan siapa yang berhak menggunakan fungsi tersebut.

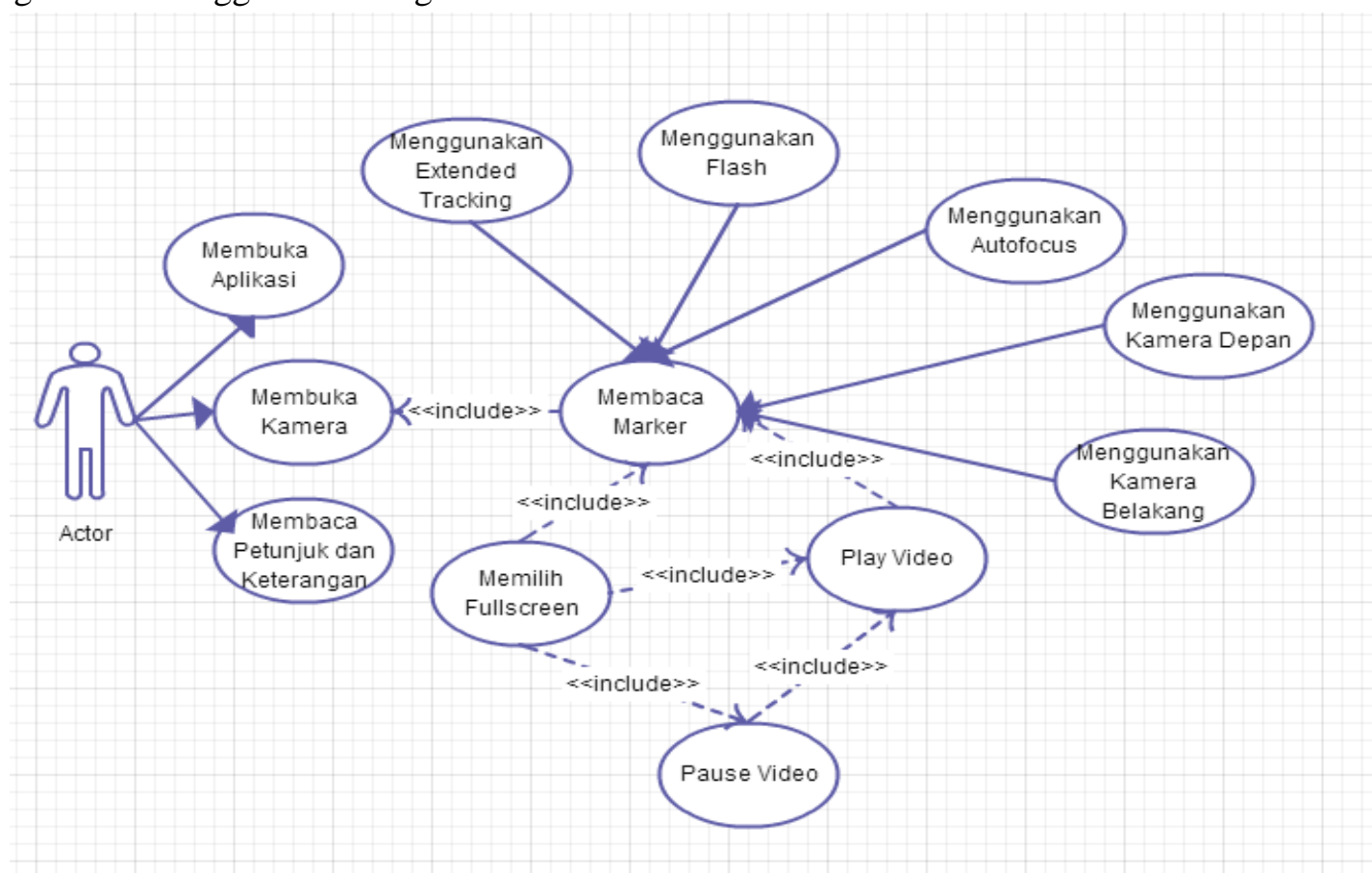

Gambar 2. Diagram Usecase Aplikasi ARBook Sejarah

Diagram usecase digunakan untuk mengetahui fungsi apa saja yang ada di dalam sebuah sistem dan siapa yang berhak menggunakan fungsi tersebut. (Lampiran 3. Definisi Usecase, Lampiran 4. Skenario Usecase, Lampiran 5. Activity Diagram). 
2364 Studi Kelayakan dan Perancangan Arbook Indonesian History: Media Pembelajaran Sejarah Menggunakan Augmented Reality - Hardika Dwi Hermawan, Thaufik Probowasito, Agatha Saputri, Dita Puji Rahayu, Nur Kholifah Putri Taufani

DOI: https://doi.org/10.31004/edukatif.v3i4.1213

\section{Hasil Pengembangan Aplikasi "ARBook-Sejarah"}

Pada karya tulis ini produk yang dihasilkan adalah aplikasi "ARBook-Sejarah" menggunakan Augmented Reality Technology dan buku sejarah. Berikut unjuk kerja dan pemaparan hasil kerja dari sistem.

a. Buku Sejarah Indonesia

Buku Sejarah adalah buku yang digunakan sebagai media cetak yang berisi materi sejarah pergerakan nasional. Buku Sejarah berisi sejarah Indonesia dari kebangkitan nasional hingga kemerdekaan Indonesia. Halaman-halaman pada buku sejarah dapat dilihat pada gambar 3.

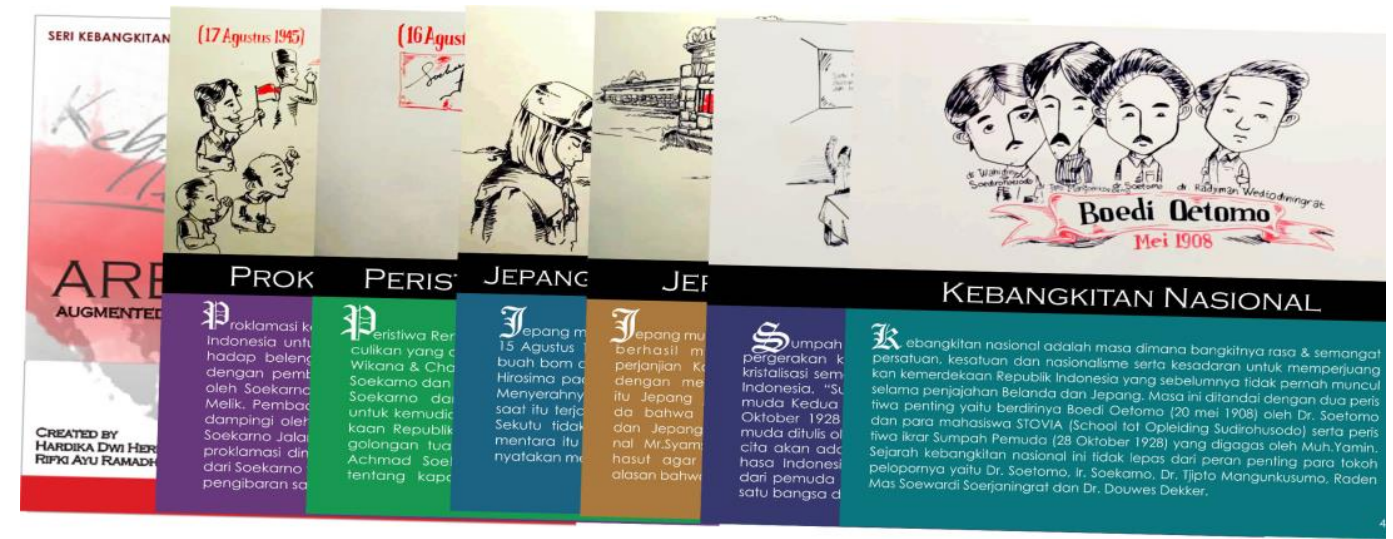

Gambar 3. Buku Sejarah

Pada setiap halaman buku sejarah, selau disertai gambar paga bagian atas penjelasan. Gambar tersebut sebelumnya telah dimasukan dalam database aplikasi, sehingga ketika gambar tersebut diarahkan melalui smartphone, maka gambar tersebut akan berubah menjadi video berjalan.

b. Aplikasi ARBook-Sejarah

Aplikasi ARBook-Sejarah merupakan satu paket dengan Buku Sejarah. Aplikasi ARBook-Sejarah berfungsi membaca gambar yang ada pada halaman buku sejarah. Icon aplikasi ditunjukan pada gambar 4 .

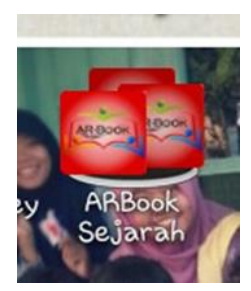

Gambar 4. Icon ARBook-Sejarah pada Android

Cara Kerja “ARBook-Sejarah"

Klik shortcut aplikasi "ARBook-Sejarah" pada Android. 
2365 Studi Kelayakan dan Perancangan Arbook Indonesian History: Media Pembelajaran Sejarah Menggunakan Augmented Reality - Hardika Dwi Hermawan, Thaufik Probowasito, Agatha Saputri, Dita Puji Rahayu, Nur Kholifah Putri Taufani

DOI: https://doi.org/10.31004/edukatif.v3i4.1213

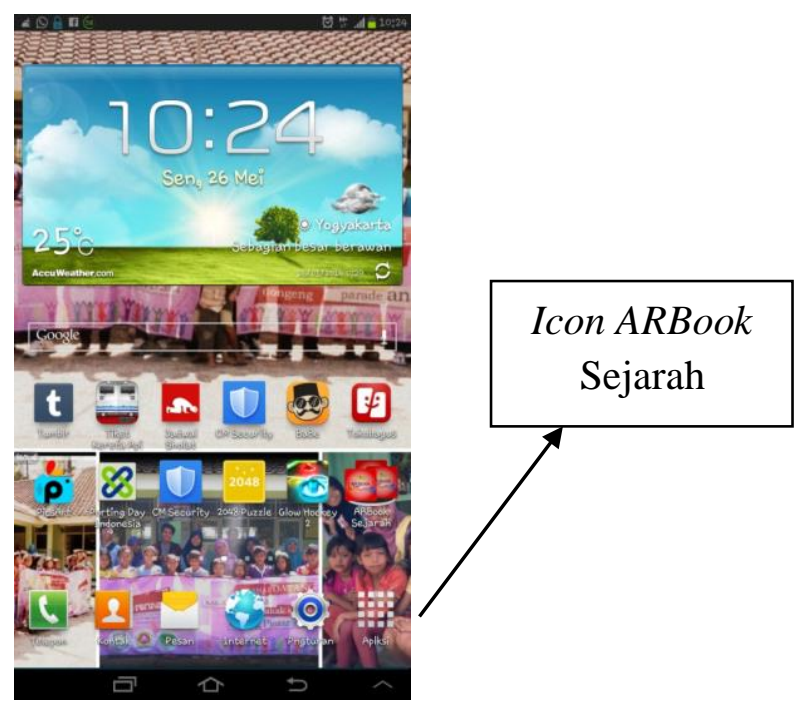

Gambar 5. Shortcut Aplikasi ARBook-Sejarah

Setelah memilih icon aplikasi pada smartphone, halaman yang akan ditampilkan adalah halaman splashcreen yang ditunjukan pada gambar 6 .

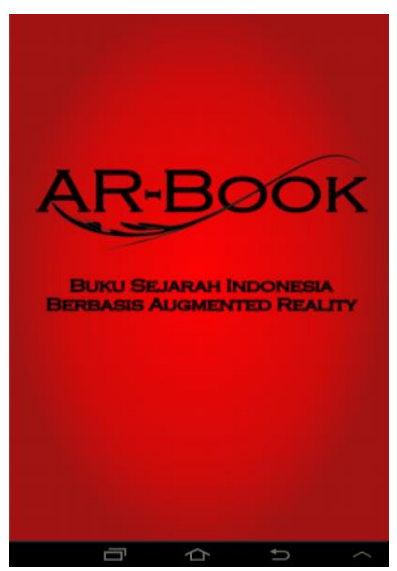

\section{Gambar 6. Halaman Splashcreen}

Setelah splashcreen, halaman selanjutnya adalah halaman awal aplikasi. Halaman awal aplikasi berisi petunjuk dan sedikit keterangan tentang aplikasi. Pada halaman ini terdapat menu start untuk memulai menggunakan aplikasi. 
2366 Studi Kelayakan dan Perancangan Arbook Indonesian History: Media Pembelajaran Sejarah Menggunakan Augmented Reality - Hardika Dwi Hermawan, Thaufik Probowasito, Agatha Saputri, Dita Puji Rahayu, Nur Kholifah Putri Taufani

DOI: https://doi.org/10.31004/edukatif.v3i4.1213
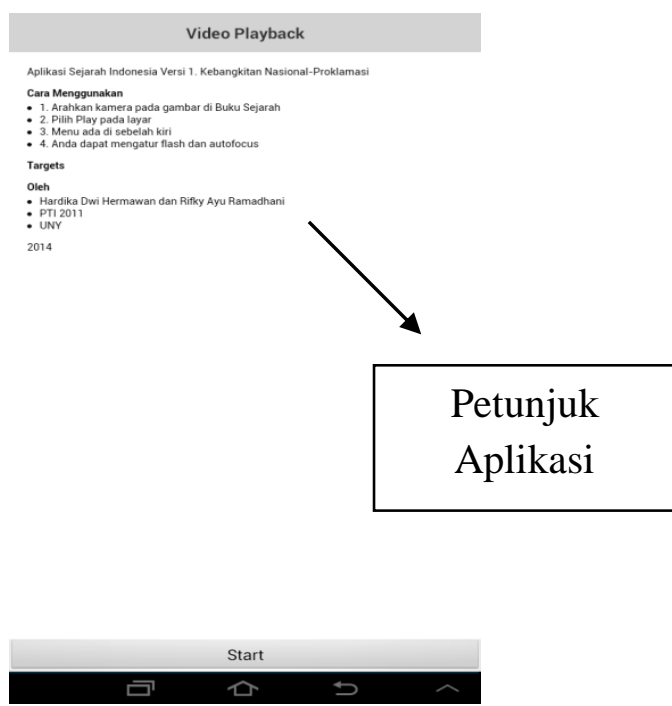

\section{Gambar 7. Halaman Awal Aplikasi}

Setelah memilih menu start, kamera pada smartphone akan ditampilkan. Kamera tampil merupakan fitur pokok untuk melakukan pembacaan marker. User cukup mengarahkan kamera pada Buku ARBook Sejarah Indonesia untuk menggunakan aplikasi. Hasilnya ditampilkan seperti gambar 8.

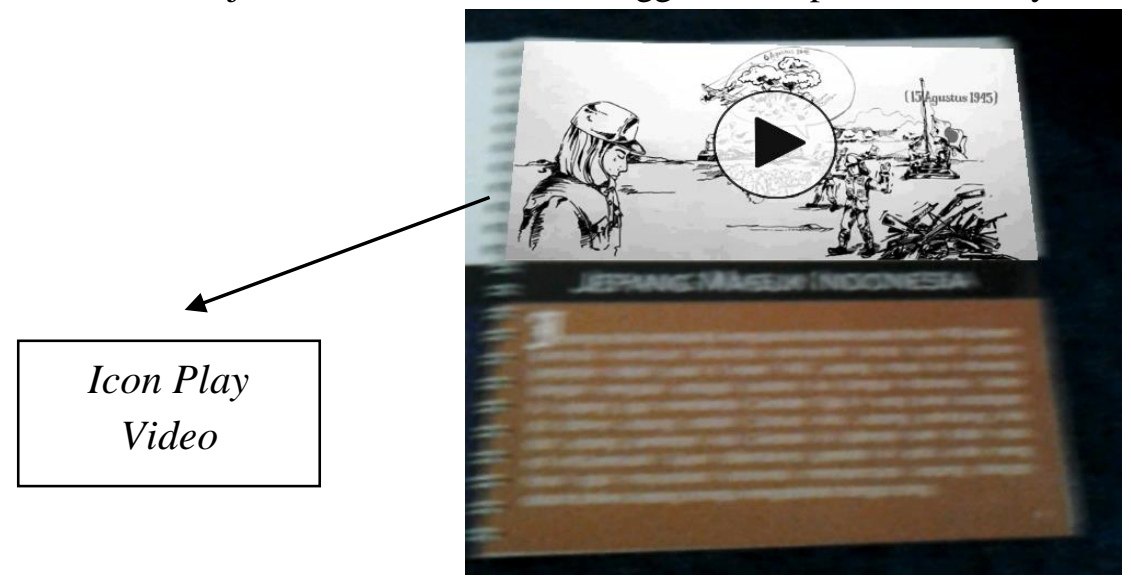

Gambar 8. Ketika dihadapkan kamera Android

Untuk memulai menampilkan video pada buku, user hanya perlu menekan tombol play pada layar smartphone. Maka video akan berjalan seperti pada gambar 9. Untuk pause video, cukup tekan video pada layar smartphone maka video akan berhenti. 
2367 Studi Kelayakan dan Perancangan Arbook Indonesian History: Media Pembelajaran Sejarah Menggunakan Augmented Reality - Hardika Dwi Hermawan, Thaufik Probowasito, Agatha Saputri, Dita Puji Rahayu, Nur Kholifah Putri Taufani

DOI: https://doi.org/10.31004/edukatif.v3i4.1213

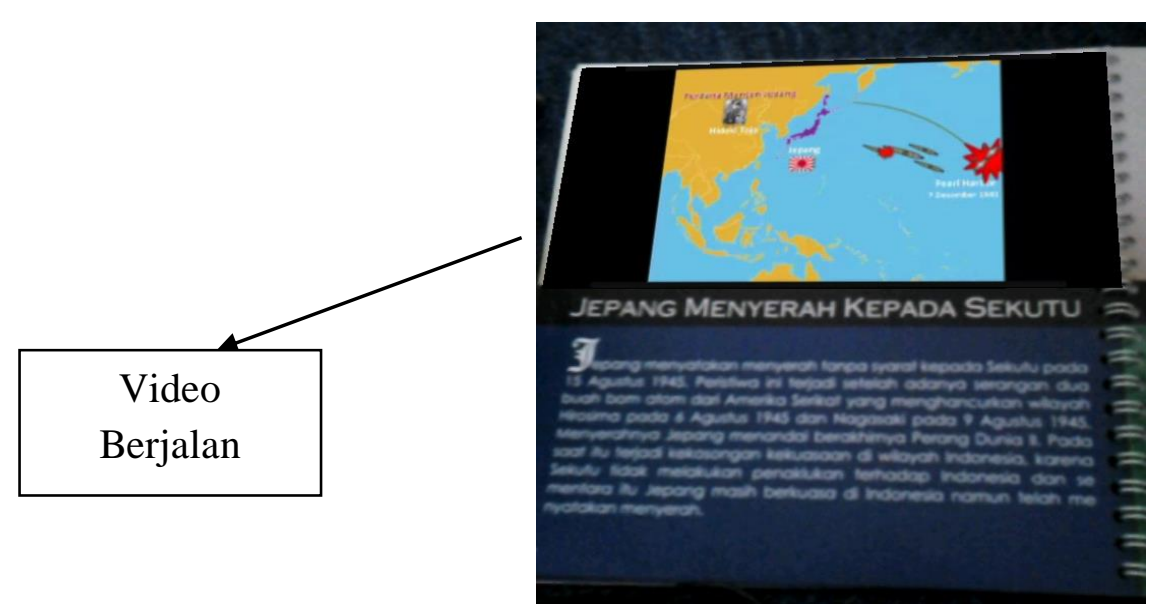

Gambar 9. Video Berjalan

Untuk menampilkan video secara penuh atau fullscreen, user hanya perlu menekan dua kali pada video di layar. Maka akan ditampilkan halaman seperti pada gambar 10. Ketika tampilan fullscreen, user tidak perlu lagi mengarahkan kamera ke marker pada buku. Untuk kembali ke tampilan semula, user tinggal menekan tombol back pada smartphone.

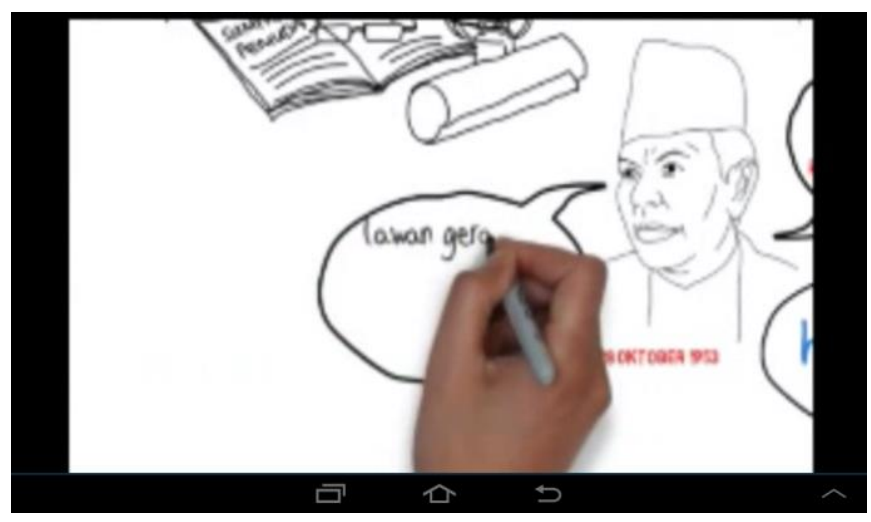

Gambar 10. Tampilan Fullscreen

Halaman menu pada aplikasi terletak pada bagian kiri. User hanya perlu menggeser layar ke kanan atau tekan 2 kali pada layar (jangan tekan pada marker), maka menu ditampilkan. Halaman menu ditunjukan pada gambar 12. Halaman menu berisi beberapa fungsi yaitu 1) Extended Tracing, 2) Flash, 3) Autofocus, 4) Kamera depan dan 5) Kamera belakang 
2368 Studi Kelayakan dan Perancangan Arbook Indonesian History: Media Pembelajaran Sejarah Menggunakan Augmented Reality - Hardika Dwi Hermawan, Thaufik Probowasito, Agatha Saputri, Dita Puji Rahayu, Nur Kholifah Putri Taufani

DOI: https://doi.org/10.31004/edukatif.v3i4.1213

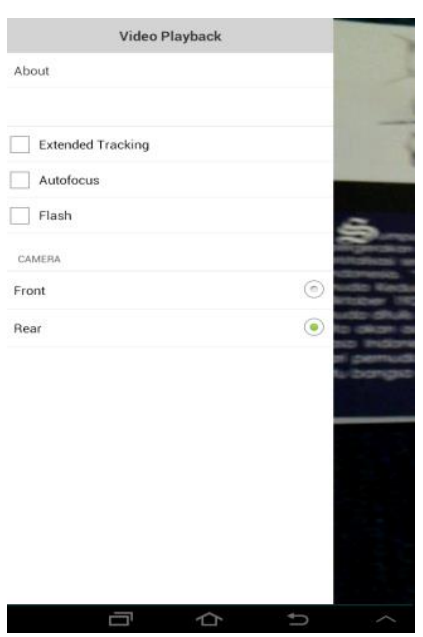

Gambar 11. Halaman Menu Aplikasi

Menu Extended Tracking digunakan untuk memusatkan marker agar tidak mudah terganggu oleh pergerakan kamera. Ketika menggunakan menu ini marker akan tetap terbaca walau kamera sejauh >1,5 meter. Seperti ditunjukan pada gambar 12.

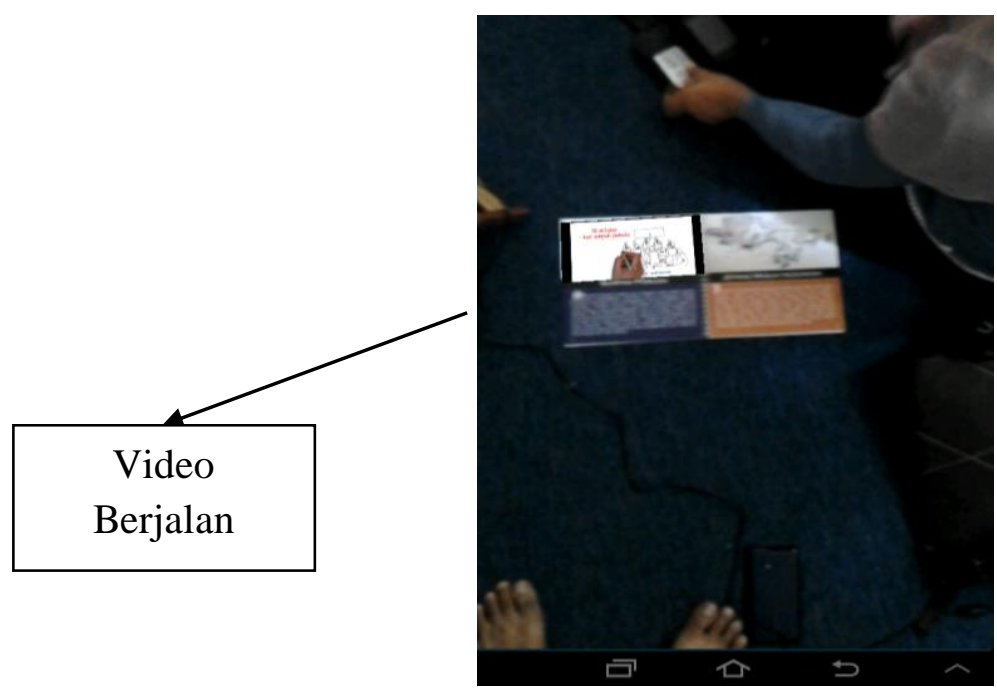

Gambar 12. Menggunakan Menu Extended Tracking

Jika smartphone android yang digunakan memiliki flash dan autofocus, maka menu ini dapat digunakan. Menu Flash digunakan untuk mengaktifkan flash apabila cahaya dalam ruangan redup atau kurang. Menu autofocus digunakan untuk memfokuskan objek pada kamera.

\section{Pengujian Kualitas Aplikasi}

Pengujian alfa dilakukan untuk mendapatkan hasil analisis kualitas dari perangkat lunak yang dikembangkan. Hasil pengujian ini berupa hasil angket penelitian oleh ahli media dari segi fungsionality, reability, portability, maintainability, dan efficiency (ISO 9126-1. Pengujian Buku Kerajinan Jogja dilakukan oleh pengembang dibantu oleh 2 orang ahli perangkat lunak. Tabel 3 merupakan hasil pengujian media yang dilakukan dari segi fungsionality, reability, portability, maintainability, dan efficiency. Berdasarkan hasil pengujian yang dilakukan oleh ahli media, kualitas aplikasi dari segi fungsionality sebesar $87,5 \%$, reliability 
2369 Studi Kelayakan dan Perancangan Arbook Indonesian History: Media Pembelajaran Sejarah Menggunakan Augmented Reality - Hardika Dwi Hermawan, Thaufik Probowasito, Agatha Saputri, Dita Puji Rahayu, Nur Kholifah Putri Taufani

DOI: https://doi.org/10.31004/edukatif.v3i4.1213

$80,0 \%$, portability $80,0 \%$, maintainability $80,0 \%$, dan dari segi efficiency sebesar $70 \%$. Secara keseluruhan presentasi kualitas aplikasi adalah sebesar 79,5\% dan masuk dalam katagori "Baik".

Tabel 3. Hasil Pengujian Media

\begin{tabular}{|c|c|c|c|c|c|c|c|}
\hline \multirow{2}{*}{ No } & \multirow{2}{*}{ Pengujian } & \multirow{2}{*}{$\begin{array}{c}\text { No } \\
\text { Jawaban }\end{array}$} & \multicolumn{2}{|c|}{ Ahli Media } & \multirow{2}{*}{ Total } & \multirow{2}{*}{$\%$} & \multirow{2}{*}{ Kategori } \\
\hline & & & Ahli 1 & Ahli 2 & & & \\
\hline \multirow[t]{4}{*}{1} & Fungsionality & 1 & 4 & 5 & 9 & $87,5 \%$ & Sangat \\
\hline & & 2 & 4 & 4 & 8 & & Baik \\
\hline & & 3 & 3 & 4 & 7 & & \\
\hline & & 4 & 4 & 5 & 9 & & \\
\hline \multirow[t]{3}{*}{2} & Reliability & 5 & 4 & 4 & 8 & $80,0 \%$ & Baik \\
\hline & & 6 & 4 & 4 & 8 & & \\
\hline & & 7 & 4 & 4 & 8 & & \\
\hline \multirow[t]{2}{*}{3} & Portability & 8 & 4 & 5 & 9 & $80,0 \%$ & Baik \\
\hline & & 9 & 4 & 4 & 8 & & \\
\hline \multirow[t]{2}{*}{4} & Maintainability & 10 & 3 & 4 & 7 & $80,0 \%$ & Baik \\
\hline & & 11 & 4 & 4 & 8 & & \\
\hline \multirow[t]{3}{*}{5} & Efficiency & 12 & 4 & 4 & 8 & $70,0 \%$ & Baik \\
\hline & & 13 & 3 & 4 & 7 & & \\
\hline & & \multicolumn{4}{|c|}{ Presentase rata-rata } & $79,5 \%$ & Baik \\
\hline
\end{tabular}

Aplikasi ARBook Sejarah menggunakan teknologi Augmented Reality telah melalui serangkaian proses rekayasa perangkat lunak dari desain hingga pengujian telah sesuai dengan spesifikasi. Pada tahap perancangan desain, daftar kebutuhan fungsional telah dijabarkan dalam bentuk usecase. Hasil perancangan kemudian diimplementasikan menggunakan tools pengembangan. Hasil dari implementasi, selanjutnya diuji melalui tahap uji alfa. Pengujian alfa dilakukan oleh pengembang dan para ahli untuk menganalisis kualitas perangkat lunak yang dikembangkan. Aspek kualitas perangkat lunak yang diuji pada pengujian alfa terdiri dari segi fungsionality, reability, portability, maintainability, dan efficiency. Tabel 4 menunjukan hasil pengujian alfa dan beta.

Tabel 4. Pembahasan Hasil Pengujian

\begin{tabular}{|c|c|c|c|}
\hline No. & Aspek & Hasil & Katagori \\
\hline 1. & Fungsionality & $\begin{array}{l}\text { Aplikasi dapat melakukan } 87,5 \% \text { fungsi } \\
\text { yang ada dengan benar } \\
\text { Fungsi yang ada berjalan dengan tepat } \\
\text { dan akurat }\end{array}$ & Sangat Baik \\
\hline 2. & Reliability & $\begin{array}{l}\text { Aplikasi memperoleh nilai reliability } \\
\text { sebesar } 80,0 \% \\
\text { Aplikasi tidak mudah hang, crash atau } \\
\text { berhenti mendadak } \\
\text { Aplikasi mampu bertahan dan pulih } \\
\text { dari kegagalan komponen atau } \\
\text { lingkungan }\end{array}$ & Baik \\
\hline 3. & Portability & $\begin{array}{l}\text { Aplikasi memperoleh nilai portability } \\
\text { sebesar } 80 \% \\
\text { Aplikasi dapat berjalan di berbagai }\end{array}$ & Baik \\
\hline
\end{tabular}


2370 Studi Kelayakan dan Perancangan Arbook Indonesian History: Media Pembelajaran Sejarah Menggunakan Augmented Reality - Hardika Dwi Hermawan, Thaufik Probowasito, Agatha Saputri, Dita Puji Rahayu, Nur Kholifah Putri Taufani

DOI: https://doi.org/10.31004/edukatif.v3i4.1213

\begin{tabular}{|c|c|}
\hline & $\begin{array}{l}\text { sistem operasi windows } \\
\text { Aplikasi dapat berjalan diberbagai } \\
\text { ukuran layar komputer }\end{array}$ \\
\hline Maintainability & $\begin{array}{l}\text { Aplikasi memperoleh skor } 80 \% \text { untuk } \\
\text { maintainability } \\
\text { Aplikasi dapat diubah dan diugrade } \\
\text { versi }\end{array}$ \\
\hline $\begin{array}{ll}5 . & \text { Efficiency }\end{array}$ & $\begin{array}{l}\text { Aplikasi memperoleh skor efficiency } \text { Baik } \\
\text { sebesar } 70 \% \\
\text { Aplikasi tidak memakai memori yang } \\
\text { berlebihan } \\
\text { Aplikasi memiliki algoritma program } \\
\text { yang efisien }\end{array}$ \\
\hline
\end{tabular}

Hasil penelitian ini sejalan dengan penelitian yang telah dilakukan oleh (Hae \& Rezeki Patricia Tantu, 2021); (Aprilia \& Iswendi, 2021); (Saputri et al., 2020) yang mengatakan bahwa media pembelajaran dengan memanfaatkan teknologi dapat digunakan untuk mendukung pembelajaran. AR dalam pembelajaran sejarah juga telah dimanfaatkan pada beragam jenis sejarah seperti pengembangan Candi-Candi masa singosari oleh (Efendi, et al., 2018), dan pengenalan bangunan sejarah kota jambi menggunakan AR (Nugroho et al., 2019). Kedua penelitian tersebut juga menghasilkan hasil yang significan. Namun, hingga saat ini memang masih jarang ditemukan media pembelajran sejarah menggunakan AR yang diintegrasikan sesuai dengan mata pelajaran pada sekolah, khususnya materi sejarah kemerdekaan dan perang dunia II. Oleh karena itu, ARBook Sejarah Indonesia menjadi salah satu alternatif media yang digunakan oleh guru untuk mendukung pembelajran Sejarah. Namun, pengembangan ARBook sejarah Indonesia ini masih memerlukan pengembangan lebih lanjut. Materi yang dikembangkan masih terpusat pada perjuangan kemerdekaan dan perang dunia dan masih sangat tergantung dengan kondisi pencahaan.

\section{KESIMPULAN}

Berdasarkan hasil dan pembahasan, maka dapat diketahui bahwa media pembelajaran sejarah dapat dikembangkan dengan menggunakan teknologi augmented reality dengan mengikuti serangkaian proses rekayasa perangkat lunak dari desain hingga implementasi sesuai dengan standar. Penelitian ini juga mengungkapkan bahwa pengujian media pembelajaran perlu dilakukan berdasarkan standar kualitas dan kelayakan yang berlaku serta sesuai dengan best practice mobile learning yaitu menguji dari aspek fungsionality, reliability, portability, maintainability, efficiency dan juga usability. Hasil pengujian ARBook menghasilkan bahwa media pembelajaran ARBook Sejarah Indonesia layak untuk digunakan. Namun, beberapa aspek perlu menjadi perhatian dalam pengembangan lebih lanjut seperti kualitas konten, variasi materi sejarah, dan juga akurasi dari kamera yang digunakan.

\section{DAFTAR PUSTAKA}

Ainina, I. A. (2014). Pemanfaatan Media Audio Visual Sebagai Sumber Pembelajaran Sejarah. Indonesian Journal Of History Education, 3(1).

Aprilia, Y., \& Iswendi, I. (2021). Pengembangan Permainan Ular Tangga Kimia Berbasis Android Sebagai Media Pembelajaran Pada Materi Senyawa Hidrokarbon Di Sekolah Menengah Atas. Edukatif: Jurnal Ilmu Pendidikan, 3(4), 1220-1230. Https://Edukatif.Org/Index.Php/Edukatif/Article/View/548

Azmi, M. (2015). Pengembangan Mobile Learning Sebagai Alternatif Media Pembelajaran Di Masa Depan. 
2371 Studi Kelayakan dan Perancangan Arbook Indonesian History: Media Pembelajaran Sejarah Menggunakan Augmented Reality - Hardika Dwi Hermawan, Thaufik Probowasito, Agatha Saputri, Dita Puji Rahayu, Nur Kholifah Putri Taufani

DOI: https://doi.org/10.31004/edukatif.v3i4.1213

Program Studi Teknologi Pendidikan Universitas Sebelas Maret, November, 102-114. Http://Repository.Unib.Ac.Id/490/1/04. Isi Vol X 2012 - Nurul Astuty Yensi 024-035.Pdf

Efendi, M. Y., Lutfi, I., Utami, I. W. P., \& Jati, S. S. P. (2018). Pengembangan Media Pembelajaran Sejarah Augmented Reality Card (Arc) Candi-Candi Masa Singhasari Berbasis Unity3d Pada Pokok Materi Peninggalan Kerajaan Singhasari Untuk Peserta Didik Kelas X Kpr1 Smk Negeri 11 Malang. Jurnal Pendidikan Sejarah Indonesia, 1(2), 176-187. Https://Doi.Org/10.17977/Um033v1i22018p176

Gall, M. D., Borg, W. R., \& Gall, J. P. (1996). Educational Research: An Introduction. Longman Publishing.

Hae, Y., \& Rezeki Patricia Tantu, Y. (2021). Penerapan Media Pembelajaran Visual Dalam Membangun Motivasi Belajar Siswa Sekolah Dasar. Edukatif: Jurnal Ilmu Pendidikan, 3(4), 1177-1184. Https://Doi.Org/10.31004/Edukatif.V3i4.522

Hasan, S. M. (2019). Pendidikan Sejarah Untuk Kehidupan Abad Ke 21. Historia: Jurnal Pendidik Dan Peneliti Sejarah, Ii(2), 61-72.

Hermawan, H. D., \& Arifin, F. (2015). The Development And Analysis Of Quality Of »Batik Detector» As A Learning Media For Indonesia Batik Motifs Android Based In Indonesian School Of Singapore. Proceedings 2015 International Conference On Science And Technology, Ticst 2015, November 2015, 281-287. Https://Doi.Org/10.1109/Ticst.2015.7369371

Laws, S., Harper, C., Jones, N., \& Marcus, R. (2013). Research For Development: A Practical Guide. Sage.

Nugroho, A., Jusia2, P. A., \& Wijaya, I. S. (2019). Deteksi Pengenalan Bangunan Sejarah Kota Jambi Menggunakan Augmented Reality. Processor: Jurnal Ilmiah Sistem Informasi, Teknologi Informasi Dan Sistem Komputer, 14(2), 87-93.

Riduwan Engkos, A. K. (2012). Cara Menggunakan Dan Memaknai Path Analysis (Analisis Jalur). In B. Alma (Ed.), Bandung: Alfabeta.

Saputri, A., Sukirno, S., Kurniawan, H., \& Probowasito, T. (2020). Developing Android Game-Based Learning Media "Go Accounting" In Accounting Learning. Indonesian Journal On Learning And Advanced Education (Ijolae), 2(2), 91-99. Https://Doi.Org/10.23917/Ijolae.V2i2.9998

Sari, R. C., Sholihin, M., Yuniarti, N., Purnama, I. A., \& Hermawan, H. D. (2021). Does Behavior Simulation Based On Augmented Reality Improve Moral Imagination? Education And Information Technologies, 26(1), 441-463. Https://Doi.Org/10.1007/S10639-020-10263-8

Sugiyono. (2009). Metode Penelitian Pendidikan Pendekatan Kuantitatif, Kualittatif, Dan R \& D. Alfabeta.

Suryani, N. (2016). Pengembangan Media Pembelajaran Sejarah Berbasis It. Sejarah Dan Budaya: Jurnal Sejarah, Budaya, Dan Pengajarannya, 10(2), 186-196. Https://Doi.Org/10.17977/Um020v10i22016p186

Syahbandi, M. R. (2021). Ilmu Sejarah Sebagai Pengembangan Dalam Kesadaran Berbangsa. 199-208.

Syahputra, I., Haryanto, E. V, \& ... (2020). Implementasi Augmented Reality Dalam Pembuatan Media Informasi Wisata Sejarah Kota Medan Berbasis Android. ... Fakultas Teknik Dan ..., 569-582. Http://EJournal.Potensi-Utama.Ac.Id/Ojs/Index.Php/Ftik/Article/View/907

Wahyudhi, J. (2014). Video Game Sebagai Media Pembelajaran Sejarah (Suatu Alternatif Dalam Menyelenggarakan Pembelajaran Sejarah). Sosio Didaktika: Social Science Education Journal, 1(2). Https://Doi.Org/10.15408/Sd.V1i2.1262

Yoga Agustin, D. S. (2011). Penurunan Rasa Cinta Budaya Dan Nasionalisme Generasi Muda Akibat Globalisasi. Jurnal Sosial Humaniora, 4(2), 177-185. Https://Doi.Org/10.12962/J24433527.V4i2.632 